\title{
The generalization of certain results for Szász-Mirakjan-Schurer operators
}

\section{DAN MiclăUŞ and Ovidiu T. POP}

\section{ABSTRACT.}

The present article continues earlier research by authors, in order to reach two goals. Firstly, we give a general formula concerning calculation of the test functions by Szász-Mirakjan-Schurer operators and secondly, we establish a Voronovskaja type theorem, the uniform convergence and the order of approximation using the modulus of continuity for the same operators.

NORTH UNIVERSITY OF BAIA MARE

DePARTMENT OF MATHEMATICS AND COMPUTER SCIENCE

VICTORIEI 76, 430122 BAIA MARE, ROMANIA

E-mail address: danmiclausrz@yahoo.com

National College "Mihai Eminescu"

Mihai Eminescu 5, 440014 SATU MARE, Romania

E-mail address: ovidiutiberiu@yahoo.com 